\title{
Rationality in the Slum: \\ An Essay on Interpretive Sociology
}

\author{
ALEJANDRO PORTES
}

University of Texas, Austin

\section{INTRODUCTION}

The peripheral slum population in urban Latin America is still characterized, despite much research to the contrary, as a focus of discontent and political disruptiveness. ${ }^{1}$ The resilience of this approach lies in its being imbedded in a more general and unquestionably accepted definition of the slum population as culturally primitive and, hence, most frequently irrational.

The hypothesis of slum radicalism is a derivation in political sociology of the general theory of political extremism, as developed by non-Marxist authors. For Lipset, ${ }^{2}$ working-class radicalism is a consequence of workingclass authoritarianism. Feelings of aggressiveness generated during early socialization, admiration of force inherited from parents, lack of education, absence of information, social uprootedness, and alienation are components of the mental set of the poor. They prevent a profound understanding of the meaning of democracy and the rules of democratic compromise and lead, on the contrary, to cravings for the social belonging and pseudosecurity offered by the totalitarian movement. For Kornhauser, ${ }^{3}$ absence of meaningful social links with the local community and personal isolation are traits predominantly found in the working classes. They make extremist movements increasingly attractive as a vehicle for the discharge of aggression and as a source of meaning and security.

In all cases radicalism is denied substantive ground on the basis of ob-

The research on which this paper is partially based was supported by the Midwest Universities Consortium for International Activities (MUCIA). The author is grateful to Professors David Chaplin, A. O. Haller, and Daniel Goldrich for their critical readings of previous versions. Whatever shortcomings the paper may contain are, however, the sole responsibility of the writer.

1 See, for example, Tad Szulc, Winds of Revolution: Latin America Today and Tomorrow (New York: Praeger, 1965). A detailed analysis and critique of these views are found in Joan M. Nelson, Migrants, Urban Poverty, and Instability in Developing Nations (Cambridge, Mass.: Harvard University Press, 1969); also Daniel Goldrich, 'Toward the Comparative Study of Politicization in Latin America' in Dwight B. Heath and Richard N. Adams (eds.), Contemporary Cultures and Societies in Latin America (New York: Random House, 1965), pp. 36178.

2 Seymour Martin Lipset, Political Man (Garden City, N.Y.: Anchor Books, 1963), chapter 4

3 William Kornhauser, The Politics of Mass Society (New York: The Free Press, 1959). 
jective conditions. It is characterized rather as a simplistic emotional response to irrational psychological needs. Though this definition is open to question, the point of interest here is the characterization of the individual poor by these theories. The poor are radical because they are culturally backward. The possibility of rational action, of a deliberate calculation of means and ends is seldom contemplated. Rather, popular masses are perceived as governed by impulse. Extremism permeates these groups to the extent that they are also permeated by ignorance, social isolation, and irrational aggressiveness.

When the definition of leftist extremism proposed by these views is accepted, as is the case with many students of Latin American urbanization, ${ }^{4}$ the obvious next question concerns who the most primitive and isolated sectors of the population are. Among them, surely extremism is likely to run rampant. In the context of urban Latin America, the question invariably draws an accusing finger toward the lower-class slum. It is consensually established that life in the peripheral slum lacks the minimum standards of mutual respect, knowledge and information, and rational striving after cultural goals found in middle- and upper-class areas and even in inner-city working-class sectors. Thus, the link between dependent and independent variables posited by the general theory is transported to the setting of the Latin American city and transformed into the notion of slum radicalism.

The important point, therefore, is that a critical examination of this notion implies by necessity examination of the general assumption on which it is based: that of irrationality as the fundamental characteristic of slum life. Once the focus of interest shifts to this aspect, it is found that the assumption of irrationality also underlies the two other theories which, together with the notion of slum radicalism, dominate the current scientific approach to these areas.

Though not used in this sense by its originator, Lewis's notion of the 'subculture of poverty' has come to denote a situation in which people are trapped in a social environment characterized by apathy, fatalism, lack of aspirations, exclusive concern with immediate gratifications, and frequent endorsement of delinquent behavior. Not only material, but moral destitution as well, is an essential part of slum life. People who are forced to move there are lost. Regardless of their initial aspirations and willingness to work, the overwhelming social influence exercised by the new environment soon eliminates these qualities, substituting for them completely new definitions of society and life.

\footnotetext{
4 See, for example, Karl Schmitt and David Burks, Evolution or Chaos: Dynamics of Latin American Government and Politics (New York: Praeger, 1963). Also Szulc, op. cit.

5 Oscar Lewis, 'The Culture of Poverty', Scientific American, 215 (October 1966), pp. 19-25; and Oscar Lewis, Antropologia de la Pobreza (Mexico City: Fondo de Cultura Economica, 1962).
} 
The theory of marginality ${ }^{6}$ is mainly a European and Latin American creation. Unlike the 'subculture-of-poverty' view, this theory recognizes the existence of aspirations among slum dwellers. Nonattainment of these aspirations is not due to the fact that people are trapped by a culture of apathy but to their bringing with them from rural areas a baggage of traditional norms and values which prevents their successful adaptation to the urban style of life. The problems which confront slum dwellers are, thus, not so much the consequence of structural arrangements limiting the availability of occupational and housing opportunities as they are the outcome of the shortcomings of individual migrants. They lack the occupational skills and modern values necessary to succeed and, thus, they are pushed out to the social and geographical margins of urban society.

The approach to be presented below does not differ from the others in imputing to slum dwellers certain psychological traits and cultural values. The effort is made, however, to understand the meaning of their actions as they are actually intended. No claim is made that this attempt at interpreting their situation will be accurate in the sense of exactly reproducing the motives of individual settlers or of groups of them when acting in this role. Here, Weber's statement that in the great majority of cases actual action goes on in a state of inarticulate half-consciousness or actual unconsciousness of its subjective meaning'7 holds. Although we assume that when submitted to the actors the present interpretation will be judged more accurate than others, its theoretical abstractness makes this criterion a poor one. It is rather the relative efficiency of the present approach in explaining recurrent behaviors in these areas and its accuracy in predicting future ones which will justify the introduction.

\section{THEORIES ON BEHAVIOR OF SLUM DWELLERS}

The imputation of irrationality always involves a negation that action is guided by a subjectively anticipated sequence of behaviors toward a goal, be it altruistic or directed to self-gain. Irrationality is closely linked with impulsiveness insofar as action is elicited by blind psychological forces rather than deliberate calculation. The assumption of irrationality underlying the above theories on the Latin American slum is made clear by placing them in the context of Weber's classic typology of social action.

Weber considers four main types of action. They can be classified according to mode of orientation. The first type emphasizes ends of an essentially utilitarian, reward-maximizing quality. Means are rational insofar as

\footnotetext{
- Guillermo Rosenbluth, 'Problemas Socio-economicos de la Marginalidad y la Integracion Urbana', Revista Paraguaya de Sociologia, 11 (1968). Also R. Hoffmann, N. Garcia, O. Mercado, and F. Uribe, 'La Marginalidad Urbana' in DESAL, Marginalidad en America Latina (Barcelona: Herder, 1969), chapter 2.

7 Max Weber, The Theory of Social and Economic Organization, Henderson and Parsons (trans.) (New York: The Free Press, 1965), p. 111.
} 
chosen by instrumental considerations alone; i.e. furnishing the fastest, most secure, and least costly path to goal-attainment. This type of social action can thus be labelled rational-utilitarian. Value-rationality, the second mode of orientation, involves a similar use of means but the goals are ideological or altruistic rather than self-serving. The last two types are not rational insofar as they do not involve a calculated sequence of acts exclusively aimed at securing attainment of a purpose. Emotional action is impulsive. It appears as a spontaneous discharge of internal influences rather than as motivated conduct. Traditional action is a result of past conditioning. It does not pursue a goal, but simply activates habitual tendencies. 8

The subculture-of-poverty approach envisions behavior in peripheral slums in terms fitting Weber's type of emotional orientation to action. Individuals are guided by the concerns of immediate gratification rather than by the expectation of future goal-attainment. Action acquires an impulsive, unpredictable quality insofar as it is directed either by shifting emotions or by complete indifference. 'Sociologically it is a way of life, a subculture with its own set of norms and values, which is reflected in poor sanitation and health practices, deviant behavior, and characteristic attributes of apathy and social isolation.'9

The city contains subcultures as stable as conventional norms and it is to one of them that the newcomer is integrated. If he adapts successfully, it will become more difficult to interest him in the values of the dominant culture. The subculture that characterizes the slums is generally defined as conformist, intolerant, poor in leadership and quasicriminal.10

The theory of marginality, on the other hand, corresponds to Weber's type of traditional orientation to action since it emphasizes the customoriented nature of social conduct in the slum: "Not only are they not modern by any definition of modernity but they are traditional insofar as they represent the actual projection of initial preconquest, pre-industrial situations'.11 'The marginal is, in some sense, 'another man' with different values and attitudes; with aspirations but operating on the basis of mechanisms totally incapable of fulfilling them; he is a diminished man ... in respect to his initiative and capacity to act individually and socially'.12

When the inhabitant of the slum is perceived in terms of his potential radicalism, his behavior is again assumed to be emotion-based. The affective impulsiveness of social action is not, however, the spontaneous, irregu-

8 Ibid., p. 115.

9 Marshall B. Clinard, 'Urbanization, Urbanism, and Deviant Behavior in Puerto Rico' in Social Change and Public Policy (San Juan: Social Science Research Center, University of Puerto Rico, 1968), p. 29.

10 Peter Marris, 'A Report on Urban Renewal in the United States' in The Urban Condition (New York: Basic Books, 1963).

11 Roger Vekemans and I. S. Fuenzalida, 'EI Concepto de Marginalidad' in DESAL, op. cit., p. 50.

12 lbid., p. 59. 
lar emotionality of a subculture of poverty but a much more dangerous one for it is the driving force of frustration and primitivism. Massive destruction of the urban middle class by an evergrowing and ever more extremist slum populace is the fearful possibility suggested by this version of slum irrationality.

All over the world, often long in advance of effective industrialization, the unskilled poor are streaming away from subsistence agriculture to exchange the squalor of rural poverty for the even deeper miseries of the shantytowns, 'favelas' and 'bidonvilles' that, year by year, grow inexorably on the fringes of the developing cities. They . . . are the core of local despair and disaffection.... Unchecked, disregarded, left to grow and fester, there is here enough explosive material to produce in the world at large the pattern of a bitter class conflict ...., threatening ultimately the security even of the comfortable West. ${ }^{13}$

As an alternative to the above three views, it will be suggested that social conduct in the Latin American urban slum can best be understood as fundamentally rational insofar as it involves, for the immense majority of participants, a calculated sequence of actions aimed at the attainment of realistic ends. This hypothesis would approach events in the slum from the perspective of Weber's type of rational-utilitarian orientation to action since means are selected not on the basis of altruistic values but through considerations of self-interest. As corollaries of this view, it will be hypothesized that:

(1) inhabitants of these areas are, to a large extent, members of upwardly mobile sectors of the urban lower class. As such, they will recurrently engage in behavior patterns that provide the fastest and most efficient way of securing socioeconomic rewards;

(2) though coming from lower educational levels, the general orientation of these people to life, and their interests and values, do not differ significantly from those of the more established urban middle classes;

(3) desperate political action, in the form of radicalism, is to a large extent absent; though frustrations of slum life are numerous, the strength and flexibility of individuals in these areas have often been underestimated.

The sections that follow present and interpret, in terms of this view, three widely-held notions about the Latin American slum. Each is directly relevant to one or the other of the three theories presented above.

\section{PARTICIPATION IN VOLUNTARY ASSOCIATIONS}

The theory of marginality has emphasized the apathetic, traditional individualism of slum populations, contrasting it with an active, modern, collective orientation.

${ }^{13}$ Barbara Ward, 'The Uses of Prosperity', Saturday Review (August 29, 1964), pp. 191-2. 
Marginality within the groups inhabiting peripheral settlements is defined by the concept of disintegration. That is, as a lack of internal cohesiveness that makes them appear atomized and dispersed. ... Dominant in these areas are isolationism and dispersion; these make them appear as disorganized groups, without internal links or coherent social expression to define them positively in front of the society as a whole. ${ }^{14}$

Participation often acquires in these writings an absolute value; no matter for what purpose or in what circumstances, it is to be automatically preferred to nonparticipation. The participant is modern and integrated, the nonparticipant is traditional and marginal. And the obvious practical lesson is the need to increase participation.

In contrast, it can be contended that participation or nonparticipation is a function of rational-utilitarian considerations. Taking part in meetings and social activities consumes time and effort; its utility, hence, must be evaluated against the economic or psychological profits derived from other activities, such as work, home improvement, family life, interaction with friends, etc. Individuals in the slum, like inhabitants of the better parts of the city, can rationally allocate time and effort in accordance with expected returns. There are problems and aspirations that do require collective action. Utilitarian considerations dictate that when problems which require communal action become relevant, participation in voluntary communal associations increases. On the other hand, solution of problems, fulfillment of aspirations, and absence in general of socially relevant issues results in decreasing participation. Organizations at such times lie dormant. They remain, however, latent as potential instruments to be employed in future confrontations. From the point of view of slum inhabitants, the communal association is not an artificial group to be maintained for its own sake, but an instrumental tool to be employed when necessary.

Data are available to test this interpretation:

1. A study by the Chilean government among a random sample of participants in the Juntas de Vecinos (communal organizations) of seventeen peripheral slums in Santiago operationalized Level of Communal Participation as an index of three moderately intercorrelated items-frequency of attendance at meetings, degree of collaboration in Junta activities, and amount of participation in Junta decisions. This index was cross-tabulated with quality of dwelling, as evaluated by respondents; with report of being or not being legal proprietor of the homesite; and with time of residence in the settlement.15 Results are presented in Table 1.

Housing improvements in slum areas are a collective enterprise. If participation in communal associations is in fact a function of their perceived utility for attainment of individual goals, it is to be expected that those in

14 Hoffmann et al., op. cit., p. 302.

15 A. Cabala Darghan, 'Estudio sobre Participación dentro de un Tipo de Asociación Voluntaria: Junta de Vecinos', Consejeria Nacional de Promoción Popular, División de Estudios, Santiago (1968) (mimeograph). 


\section{ALEJANDRO PORTES}

the worst housing conditions should participate more than those whose housing problems are less pressing. As can be seen, results in Table 1 support this conclusion.

The theory of marginality and other writings have predicted positive relationships between proprietorship and time of residence in an area, on the one hand, and participation in voluntary associations on the other. ${ }^{16}$ Proprietorship is associated with characteristics of success, responsibility, and modernity. The proprietor fits better into the image of 'responsible citizen' and 'informed individual' than the nonproprietor. Therefore, pro-

TABLE 1

Participation in 'Juntas de Vecinos' (neighborhood councils) in Santiago de Chile and Selected Determinants*

\begin{tabular}{|c|c|c|c|}
\hline \multirow[t]{2}{*}{ Variable } & \multirow[t]{2}{*}{ Category } & \multicolumn{2}{|c|}{$\begin{array}{l}\text { Percentage having high Level of } \\
\text { Participation in the local Junta }\end{array}$} \\
\hline & & $\%$ & $\mathbf{N}$ \\
\hline \multirow{3}{*}{$\begin{array}{l}\text { Evaluation of } \\
\text { present dwelling } \\
\text { by respondent }\end{array}$} & Insufficient & 31.82 & (088) \\
\hline & Regular & 24.47 & (094) \\
\hline & Sufficient & 12.04 & (108) \\
\hline \multirow{2}{*}{$\begin{array}{l}\text { Legal ownership } \\
\text { of dwelling }\end{array}$} & Nonproprietor & 35.37 & (082) \\
\hline & Proprietor & 16.83 & (208) \\
\hline \multirow{3}{*}{$\begin{array}{l}\text { Time of } \\
\text { residence } \\
\text { in area }\end{array}$} & 1 month to 7 years & 32.86 & $(070)$ \\
\hline & 8 years to 15 years & 21.55 & (116) \\
\hline & 16 years or more & 15.38 & (104) \\
\hline
\end{tabular}

* Figures in parentheses represent the total number of cases in each row over which proportions of 'high' participants were computed.

Source: Promoción Popular, 'Estudio sobre Participación en un Tipo de Associación Voluntaria: Junta de Vecinos', Santiago, Chile.

prietors should have higher levels of social participation, a behavior characterized as modern and responsible. Similarly, individuals with longer residence spans in an area are commonly the most settled and responsible inhabitants, according to this theory. Thus, higher participation should also be expected of them. As can be seen, results in Table 1 run directly contrary to these predictions. From the point of view of rational selfinterest, proprietors and long-term residents, precisely because of being better established, i.e. having solved their most pressing housing problems, have less interest in employing the communal organization as an instrument for the attainment of these goals. Thus, participation among them should

${ }^{16}$ See, for example, Hoffmann et al., op. cit. Also Charles Wright and Herbert Hyman, 'Voluntary Associations' Membership of American Adults', American Sociological Review, 23:3 (1958); and H. E. Freeman, E. Novak, and L. G. Reeder, 'Correlates of Membership in Voluntary Associations', American Sociological Review, 22:5 (1957). 
be lower than among nonproprietors and newcomers to the area. This is what the data indicate.

2. If participation in communal organizations is mainly determined by rational considerations, it can be expected that the more efficient the organization is perceived to be in promoting the interests of dwellers, the greater will be the participation in its activities. Table 2, based on the same Santiago data, strongly supports this prediction. The statistical test of significance for the table (chi square) results in a value which doubles that required for significance at the .001 level with percentages running in the predicted direction.

3. A comparative study by Goldrich ${ }^{17}$ covered two slums in Lima and

TABLE 2

Perceived effectiveness of 'Juntas de Vecinos' in Promoting Interests of Slum Dwellers and Level of Participation in them*

\begin{tabular}{lccc}
\hline \multirow{2}{*}{ Participation } & \multicolumn{3}{c}{ Effectiveness } \\
\cline { 2 - 4 } & Not effective & Effective & Very effective \\
\cline { 2 - 4 } & & 32.94 & 30.00 \\
Low & 46.59 & 38.82 & 23.33 \\
Medium & 43.18 & 28.24 & 46.67 \\
High & 10.23 & $100.00(85)$ & $100.00(88)$ \\
Totals & $100.00(88)$ & & \\
\hline
\end{tabular}

* Figures in cells are percentages; raw marginal frequencies are in parentheses.

Source: Promoción Popular, 'Estudio sobre Participación en un Tipo de Associación Voluntaria: Junta de Vecinos'.

two in Santiago. Two of these-a squatter settlement in Lima and a government-sponsored project in Santiago-were more developed, approaching in quality of dwellings and services the characteristics of established urban quarters. The others, one in each city, fitted the typical image of the slum. For the first two settlements, the more advanced and modern, the theory of marginality would predict higher participation in communal organizations than for the last two. However, results run exactly opposite to this prediction. Participation in the communal organizations of advanced settlements reaches ten percent in Lima and only six percent in Santiago. In contrast, participation in less developed settlement associations in both cities surpasses twenty percent. If rationality governs membership in organizations, those settlements having the most urgent, collectively

${ }^{17}$ Daniel Goldrich, Raymond B. Pratt, and C. R. Schuller, "The Political Integration of Lower-Class Urban Settlements in Chile and Peru', Studies in Comparative International Development, 3:1 (1967-68), p. 4. 
solvable problems should be the ones where participation is at its highest. This is, in fact, the situation portrayed by the data.

4. A more recent study by the author comprised four settlements in Santiago. The first, Villa Norte, a poor, very deteriorated slum, was perceived by its inhabitants as an unsuitable place to live. Individuals and families attempted to escape from the area by whatever means possible. Escape, however, was perceived as an individual, rather than collective, venture. The second area, Villa Sur-Oeste, an old, relatively successful government housing project for the very poor, possessed dwellings and services of considerably better quality than those in any other area. The third settlement, Villa Oeste, emerged as a result of a successful squatter

TABLE 3

Type of Peripheral Settlement and Membership in 'Junta de Vecinos' in Santiago de Chile*

\begin{tabular}{lcc}
\hline $\begin{array}{l}\text { Settlement and type } \\
\text { Percentage belonging to local 'Junta' } \\
\%\end{array}$ & 39 & $\mathbf{N}$ \\
\hline $\begin{array}{l}\text { Villa Norte } \\
\text { (slum proper) }\end{array}$ & 46 & $(071)$ \\
$\begin{array}{l}\text { Villa Sur-Oeste } \\
\text { (established government project) }\end{array}$ & 54 & $(113)$ \\
$\begin{array}{l}\text { Villa Oeste } \\
\text { (squatter settlement) }\end{array}$ & 72 & $(114)$ \\
$\begin{array}{l}\text { Villa Sur-Este } \\
\text { (new government settlement) }\end{array}$ & & \\
\hline
\end{tabular}

* Figures in parentheses are raw frequencies over which percentages were computed.

invasion. After legal title to the land was obtained, the settlement improved steadily though, at the time of the survey, it was still plagued by numerous problems. The fourth area, government-sponsored Villa Sur-Este, aimed at providing very poor families with an urbanized lot on which to build their homes. Though lots were assigned by the government, settlers had not been given legal title to the land and this insecurity was compounded by many other problems, such as lack of several basic services.

The four settlements had organized Juntas de Vecinos. A rational approach would again predict that the area where the Junta had greatest functionality for meeting the needs and promoting the interests of settlers would also yield the highest rates of communal participation. In this case Villa Sur-Este, the newest and most troubled area, would be expected to exhibit this pattern since in no other area would the Junta be as useful as here. Results, presented in Table 3, support this prediction. 
To be noticed also is the high proportion of Junta members in Villa Oeste. Though older and more established than Villa Sur-Este, conditions in this squatter settlement were far from satisfactory. This again led to increased interest and participation in collective activities as vehicles for improvement. Low participation, in agreement with the present view and contrary to the theory of marginality, occurs in the oldest, most established and best area, Villa Sur-Oeste. The most modern and most satisfied are the least participant since obviously the Junta has ceased to fulfill a crucial function in the promotion of interests.

Research by other authors confirms these findings. Mangin ${ }^{18}$ notes that in Lima's squatter 'barriadas', local associations reach the peak of their importance at the time of the organized land invasion and tend to decline thereafter as settlements become established. Goldrich ${ }^{19}$ finds the same pattern in Lima and Santiago. Some marginality theorists have also noted the dependence of Junta participation on utilitarian considerations. ${ }^{20}$ This pattern, however, is judged to be 'traditional' by them since it does not maintain stable levels of organization and participation. Participation is seen as nonsolidary precisely because it tends to disappear once the need is satisfied. What this view fails to perceive is that similar patterns can be found in more educated, 'modern', established neighborhoods. There, as in the slum, organizations emerge, grow, and decline according to their functionality in attaining the utilitarian goals of neighbors. Thus, the internal logic of the two situations is identical. Though the setting varies and, perhaps, upper-class sectors may be credited with greater foresight, the rational-utilitarian determination of conduct remains constant. If slum areas are labelled 'traditional' because they subordinate participation to the amount of and importance of expected payoffs, the same label should, in all justice, be applied to the more advanced urban neighborhoods.

\section{RESISTANCE TO HOUSING IMPROVEMENT}

Classic among Argentinian housing experts is the experience of the large apartment blocks donated by Eva Peron to meet the housing needs of Buenos Aires workers. A few months later, a great number of inhabitants had gone back to their original settlements after practically destroying the new apartments. Inhabitants of the 'favelas' of Rio de Janeiro are frequently reported to refuse to move to suburban government projects or to return to the 'favela' after having moved. For many, these are conclusive demonstrations of the existence of a negative 'slum' culture to which individuals become accustomed in such a way that they cannot liberate themselves

18 William Mangin, 'Latin American Squatter Settlements: A Problem and a Solution', Latin Research Review, 2:3 (Summer 1967), pp. 65-98.

19 Goldrich, et. al., op. cit.

20 Vekemans and Fuenzalida, op. cit., pp. 57-8. 
from its influence. Thus, it is argued, there is a need to reeducate the slum dweller before moving him to a new home.

Housing experts more closely familiar with the phenomenon have taken, however, a different stand. Abrams, for example, points out that:

Unlikely as it may seem, there are those who actually prefer their squatter shacks to what the legitimate housing market offers. They may feel that what is available is too costly or that it offers insufficient space and privacy. Public housing, even when available, may be objectionable to them as making for a more bureaucratic regulation of their private lives, or they may not cotton to the vertical way of life characteristic of the public housing projects. Some may feel that the proximity of their squatter locations to their job makes up for other shortcomings. ${ }^{21}$

With respect to housing, slums are not homogeneous. Inhabitants of some areas adamantly refuse to leave, while settlers of others direct all their efforts to escaping from them. Public housing that is rejected by some is eagerly sought by others. The question, therefore, is what are the generalized criteria, if any, governing the emergence of these differences.

Each of the three theories outlined above has taken for granted the undesirability of slum life. Thus, inhabitants are defined as those lacking the minimal necessary means to live in other quarters of the city. This in turn reflects the standard interpretation of slum growth as a direct consequence of lower-class migration. Migration, it is argued, directly creates slums by the simple fact that poor migrants generate their own ad hoc reception centers in the urban periphery. The slum, therefore, is a temporary place to be escaped as soon as means permit. Inhabitants at any point in time are those who have not been able to move into the city or those who, having moved, failed to maintain their position in it.

Such a view necessarily leads to two conclusions:

1. The population of slums is homogeneous. It is essentially a population of new migrants and, thus, of the poorest and most ignorant inhabitants of the city.

2. Lower-class migration is a uni-directional process in which attainment of progressively higher stages in the socioeconomic hierarchy coincides with increasing closeness to the city proper. From rural areas to the urban periphery to the city itself, the process of migration unfolds insofar as it is successful. Failure reverses the arrow of geographical movement. Downward mobility on the social stratification ladder leads to physical expulsion from the city into the urban periphery; finally, it may even force return to the original rural zone.

If these conclusions are true, it can be expected that most slum inhabitants would be either new migrants or individuals whom the city has rejected. Empirical findings, however, have systematically disproven these

21 Charles Abrams, 'Squatter Settlements: The Problem and the Opportunity', AID, Department of Housing and Urban Development, Washington, D.C. (1965). 
predictions. The process of migration has been found to be not uni-, but bi-directional. New migrants tend to move into central city slums in search of work opportunities. Though some find housing in the urban periphery at this stage, the peripheral settlement is more properly the abode of those having secured a minimum of occupational stability. The peripheral settlement is often an area sought after, rather than escaped from. The reason is that it offers the only opportunity to secure inexpensive or free land upon which to build a permanent home.

Results from eighteen recent studies in slum settlements in Latin America run consistently contrary to the prediction of dominant majorities of new migrants in these areas. Without exception, the highest proportions correspond to lower-class groups having considerable urban experience. Six of these studies are summarized in Table 4.22 In addition, as the findings of Flinn in Bogota and the writer in Santiago (Table 4) indicate, peripheral settlers tend to perceive their present situation as a step forward, and their housing as an improvement over what they had before.

There appear to be, therefore, two main types of slum dwellers in Latin American cities, not one. The process of lower-class migration consists of a two-step sequence in which occupational success in the city is associated with movement away from central-city slums into peripheral settlements which, despite appearances, offer the opportunities for housing improvement and land ownership.

For newcomers to the city, the 'bridgeheaders', occupation, and not housing, is the paramount consideration. Transportation from faraway areas, expensive and time-consuming, reduces the possibility of searching for an occupation. For those having secured a stable occupation, the 'consolidators', housing becomes the crucial concern. Through home ownership the attempt is made to establish definitive roots in the city. ${ }^{23}$ Hence, they settle in peripheral areas where a permanent home can be built. 'Consolidator' peripheral settlements are seldom touched by resettlement programs. However, 'bridgeheader' areas are often the object of such action. To the extent that individuals have not completed this initial stage, they will offer resistance. When implemented, premature resettlement will retard, rather than accelerate, successful integration:

Premature suburbanization of the very poor will force them to return or will cripple their progress. Prematurely suburbanized shantytowners of Rio and Santiago are often too poor to change their cultural patterns as demanded by their change of habitat so, deprived of one of their principal vehicles for social change, it is inevitable that their progress should be delayed, even if it is not permanently crippled.24

22 Others include studies in Rio de Janeiro, Caracas, Buenos Aires, Bogota, Lima, Guatemala City, Santo Domingo, and Santiago. They are excluded here for the sake of brevity. Results from these studies have been summarized and are available upon request from the author.

23 John F. C. Turner, 'Uncontrolled Urban Settlement: Problems and Policies', International Social Development Review, 1 (1968), pp. 107-30.

24 Ibid. 
TABLE 4

Proportion of City-born Settlers and Old and New Migrants in Peripheral Slums of Five Latin American Cities

Source City Year Relevant figures

Usandizaga \&
Havens: Study of
three 'barrios de
invasion'.

Flinn: Study of Bogota one 'barrio de invasion'.

Amaro: Study of Guatemala city-wide sample of adult residents in 'colonias'.

Goldrich: Study Lima of two 'barriadas'.

CELAP: City- $\quad$ Santiago wide study of adult females living in 'poblaciónes'.
Barranquilla

1965 dwellers were born in Barranquilla. Percentage of migrants $(N=169)$ having lived in Barranquilla:

$\begin{array}{lr}\text { less than } 1 \text { year } & 3.55 \\ 1 \text { to } 5 \text { years } & 20.71 \\ 5 \text { to } 10 \text { years } & 20.71 \\ 10 \text { to } 20 \text { years } & 26.63 \\ 20 \text { years or more } & 28.40\end{array}$

$196811.7 \%$ of a representative sample of 120 adult barrio dwellers were born in Bogota. $68.9 \%$ of migrants $(\mathrm{N}=106)$ lived in central city areas before coming to the barrio. $70 \%$ of those who came to the barrio after having lived in the city gave, as their reason for coming, a desire to own land and/or to improve their living conditions.

$196832 \%$ of probability sample of 1160 colonia dwellers born in Guatemala City or Quetzaltenango.

Percentage of migrants from small towns or rural areas $(N=638)$ having lived in Guatemala City:

$\begin{array}{ll}\text { less than } 5 \text { years } & 13 \\ 5 \text { to } 10 \text { years } & 18 \\ 10 \text { years or more } & 69\end{array}$

$196511 \%$ of a representative sample of 260 adult barriada dwellers born in Lima.

Percentage of migrants $(\mathrm{N}=221)$ having lived in Lima:

$\begin{array}{lr}\text { less than } 3 \text { years } & 7 \\ 3 \text { to } 5 \text { years } & 16 \\ 5 \text { to } 12 \text { years } & 24 \\ 12 \text { years or more } & 53\end{array}$

$196751 \%$ of probability sample of 1114 adult females were born in Santiago.

Percentage of migrants from small towns or rural areas $(\mathrm{N}=334)$ having lived in Santiago:

$\begin{array}{lr}\text { less than } 1 \text { year } & 3 \\ 1 \text { to } 4 \text { years } & 7 \\ 5 \text { to } 9 \text { years } & 10 \\ 10 \text { to } 14 \text { years } & 13 \\ 15 \text { to } 19 \text { years } & 20 \\ 20 \text { years or more } & 47\end{array}$


Author: Study Santiago of four 'poblaciones'.
$196942 \%$ of representative sample of 382 adult 'pobladores' were born in Santiago.

Percentage of migrants $(\mathrm{N}=222)$ having lived in Santiago:

$\begin{array}{lr}\text { less than } 1 \text { year } & 0 \\ 1 \text { to } 4 \text { years } & 8 \\ 5 \text { to } 9 \text { years } & 19 \\ 10 \text { to } 29 \text { years } & 52 \\ 30 \text { years or more } & 21\end{array}$

Percentage of migrants who: moved directly to present población moved first to the city proper and later

to the present población

Percentage of sample judging their present dwelling to be:

$\begin{array}{lr}\text { worse than before } & 18 \\ \text { the same as before } & 7 \\ \text { better than before } & 75\end{array}$

Sources: Nelson Amaro, Guatemala: Caracteristicas Sociales de sus Tres Grupos mas Representativos (Guatemala City: Central American Population and Family Center, ICAPF, 1968); CELAP (Latin American Population Center), Encuesta sobre la Familia y la Fecundidad en Poblaciónes Marginales del Gran Santiago 1966/67, vol. 2 (Santiago: CELAP, 1968); William Flinn, 'The Process of Migration to a Shantytown in Bogota, Colombia', Inter-American Economic Affairs, 22(1968) 77-88; Daniel Goldrich, Raymond B. Pratt, and C. R. Schuller, 'The Political Integration of Lower-Class Urban Settlements in Chile and Peru', Studies in International Comparative Development, 3 (1967-68), 1-22; Elsa Usandizaga and A. Eugene Havens, Tres Barrios de Invasion (Bogota: Tercer Mundo, 1966).

The line between the two main types of slum dwellers is not difficult to draw since it does not depend on theoretical considerations; individuals themselves make it very clear what stage of the process they are in: 'Consolidators' demand and often force development of suburban settlements appropriate for establishing permanent houses; 'bridgeheaders' often oppose forced resettlement into these same areas.

What should be noticed is that these criteria do not support the thesis that 'resistance to improvement' is a direct result of indoctrination in a culture of poverty. On the contrary, they obviously derive from an established priority of utilitarian goals and a rational selection of means. Land in places far away from the central city is desirable; however, it cannot be supported without a stable occupation. A new house may represent a significant improvement, yet it may be too costly. As Mangin points out, 'The few governmental attempts to build new projects have chosen sites 
that are much too far from work and have proved to be much too expensive for the squatters'. ${ }^{25}$ Thus, the effort to understand this 'escape-from-improvement' pattern on the basis of the meaning it has for slum dwellers leads to the necessity of interpreting these actions in terms of a consistent rational orientation which, regardless of the criticisms levelled at it by higher-up groups, goes its own way in the selection of the best means to attain the most important ends at each stage.

\section{SLUM RADICALISM}

Few theories have been more widely held than that of slum radicalism. Few have met with more consistent rejection from empirical research. Studies in almost every Latin American capital have found leftist extremism to be weak, or even nonexistent, in peripheral slums.

Respondents in the author's Santiago study reporting membership in the extreme-left Communist or Socialist Parties amounted to only 7 percent of the entire sample. The overwhelming preference for peaceful means in the struggle for improvement is illustrated by results from the same survey, presented in Table 5. Respondents were confronted here with an illustration of a realistic situation offering a clearcut choice between peaceful versus violent means for the attainment of revindications. As can be seen, 84 percent of the sample subscribed to the peaceful alternative.

Goldrich's study ${ }^{26}$ of peripheral settlements in Lima and Santiago presents data which also point to the weakness of leftist radicalism in slum areas. Radical attitudes, indicated by disagreement with the statement 'Violence should never be the way to resolve political problems', were, without exception, a minority in each of the four areas studied; they ranged from 38 percent in a Lima slum to 12 percent in a Santiago settlement. Similarly, disagreement with the statement 'Social change is acceptable only if it does not provoke disorder' reached 20 and 28 percent for the two Lima settlements and only 5 and 6 percent for the Santiago settlements. These figures are supported by the conclusions of most empirical investigations in these areas. Cornelius ${ }^{27}$ adequately summarizes these results:

We find little empirical evidence to support the standard conception of the city as a radicalizing environment. Nor does there appear to be an empirical basis for frequent perceptions of imminent threat to existing authority structures stemming from the rapid influx of migrants to cities. In Mexican 'colonias proletarias', as in the 'favelas' of Brazil and the 'barriadas' of Lima, contradictions between the migrant's values regarding the city as a place of economic opportunity and his actual situation seem more likely to lead: to cynical criticism of 'malfunctioning' of authority structures... than to political questioning of the legitimacy of such structures.

Political extremism as impulsive action is weak in Latin Anerican stums because the behavior of most inhabitants is guided by rational calculation

27 Wayne A. Cornelius, 'Urbanization as an Agent in Latin American Political Instability: The Case of Mexico', American Political Science Review, 63 (September 1969), p. 855. 
of means for the attainment of prespecified goals. The economic ethic of the lower-class peripheral population in Latin America is still largely misunderstood. This is particularly surprising in view of the fact that it possesses basic similarities with the immigrant ethic of the last half of the nineteenth century, and the beginning of the twentieth. The phenomenal world of immigrants and migrants alike shares three fundamental characteristics:

1. There is an individualistic ethic of promotion through personal effort. The crucial concern is not collective progress for the poorer classes, but individual advancement away from them. Germani ${ }^{28}$ notes that the massive lower-class migrations toward Buenos Aires in the last two decades have resulted in insignificant disruptions of the urban political order. He and

TABLE 5

Attitude toward Violent Means for Attainment of Revindication in Peripheral Settlements in Santiago

'Factory XYZ was occupied by its workers but they were expelled by the police. Later, the leaders of the movement met to decide what to do. One group wanted to act peacefully, going to visit congressmen and government officials and explaining the situation in the press. The other group proposed reoccupying forcefully the plant at whatever price. The two groups could not agree and finally you were called on to cast the decisive vote. What group would you have favored?'

$\begin{array}{lc}\text { The one that wanted to act peacefully } & 84 \% \\ \text { The one that wanted to occupy the factory forcefully } & 12 \\ \text { Neither of the two; does not know } & 4 \\ \text { Total } & 100 \%\end{array}$

other authors have pointed out that most migrants do in fact attain their initial aspirations, a fact which in turn reinforces the dominant individualistic orientation. Politically, the large majority of Argentinian migrants are supporters of Peronism, not of Communism.

The same orientation is reported by Cardozo, Touraine, and others in Brazil. ${ }^{29}$ There, populistic movements such as Vargaism have been supported by migrants as the political side of their strategy for self-promotion. As Mangin appropriately states, the dominant ideology of peripheral slum dwellers is very similar to the petty capitalism of nineteenth-century small businessmen in England or the United States: Work hard, save your money, outwit the state, and vote conservatively if possible, but always in your own economic interest.

2. Such an ideology tends to place the blame for economic failure on the individual or on accidental circumstances rather than on the broader

28 Gino Germani, 'Social and Political Consequences of Mobility' in Neil J. Smelser and Seymour M. Lipset (eds.), Social Structure and Mobility in Economic Development (Chicago: Aldine, 1966).

29 Fernando H. Cardoso, 'Le Proletariat brésilien', Sociologie du Travail, 4 (1961), pp. 5065; and Alain Touraine, 'Industrialisation et conscience ouvrière à São Paulo', Sociologie du Travail, 4 (1961), pp. 389-407. 
socioeconomic structure. The revolutionary potential of frustrations is deflected to the extent that the focus of blame is nonstructural.

The author's study in Santiagoasked respondents who or what was to blame for their failure to attain initial aspirations. Twelve percent reported that they had fulfilled all their aspirations. Among those for whom at least some initial goals had been frustrated, the proportion naming structural factors, such as governmental indifference or exploitation by the rich, was 7 percent as compared with 81 percent placing responsibility on nonstructural factors, such as parents, themselves, incidental events in their past, or sheer bad luck.

3. The absence of structural blame is closely linked with the fact that the lower-class migrant, like the immigrant of old, does not feel himself entitled to anything. Phenomenally, he perceives his presence in the city as the single opportunity in life to improve his lot. Migrants, as immigrants, are foreigners to the city. As such, they are more prone, at least initially, to question the legitimacy of their own presence as audacious newcomers than the general urban order. The city which offers the opportunity of upward ascent also sets its own hard rules. The migrant's decision to come to the city, like the immigrant's choice of settling in a new country, implies a tacit acceptance of these rules.

Increasing imputation of responsibility for deprivations to the general societal order is dependent on a sense of having a legitimate claim on that order. This in turn requires a feeling of belonging, of being a rightful member of the community unjustly deprived of his due. When this occurs, as some believe is increasingly happening in U.S. slums, the political consequences are indeed explosive.

The immigrant ethic, the ideology of petty capitalism dominant today in the Latin American urban periphery is devoid of such feelings. Political extremism is discarded first as illegitimate and, second, as just too costly. In the rational calculation of means and ends, the strategy of violence and mass uprising is seen as too dangerous a path.

As years transpire, three other factors also contribute to the preservation of the inclination toward utilitarian self-promotion: (1) the experience of some measure of upward mobility, (2) the limited nature of aspirations, and (3) the face-to-face contact with models who have fulfilled these aspirations through the established channels.

1. A consistent finding of studies in Latin American slum areas is that settlers evaluate their situations as better than they were at the beginning of their lives. Germani in Buenos Aires, Briones in Lima, Flinn in Bogota, Bonilla in Rio de Janeiro, Usandizaga and Havens in Barranquilla, and several others have reported subjective evaluations of upward mobility by most of their respondents in slum settlements. 30

${ }^{30}$ Gino Germani, 'Inquiry into the Social Effects of Urbanization in a Working Class Sector 
2. Part of the petty capitalistic ideology of slum areas is reflected in the limited nature of aspirations. The ghetto slum in the United States increasingly voices aspirations of a relative nature directly involving comparisons with the standards of living of the dominant sectors. ${ }^{31}$ In contrast, aspirations of Latin American slum dwellers are absolute; they do not involve comparisons, but rather a desire to achieve a minimal, secure foothold in the city. Thus, the modest scope of aspirations and their nature, which reflects the three necessary conditions for effective integrationhousing, occupational stability, and educational opportunities for children. These dominant aspirations, voiced by most of our respondents in Santiago, are also found by Mangin in Lima: 'Aspiration levels for many of the adult migrants are relatively low and many of them feel that when they have a steady income, a house of their own, and their children in school, they have achieved more than they had believed possible'. ${ }^{32}$

3. Credibility in the eventual fulfillment of these aspirations is strongly affected by the experience of individuals known to the settlers who have gone through the same steps. Because some measure of personal mobility in the past constitutes evidence that the established channels work to some extent, the first-hand proof furnished by relatives and friends who have managed to establish themselves securely in the city is a guarantee and an incentive for work along the same paths in the years to come.

\section{CONCLUSIONS}

The consistent theme underlying this paper is the fundamental similarity between individuals in the Latin American urban slum and those in the more integrated middle and upper quarters of the same cities. Slum settlers and more established groups share the same emphasis on defense and promotion of self-interests, and the same rational logic in going about this task. In the framework of Weber's typology of social action, these behaviors and psychological orientations can best be interpreted in terms of a rationalutilitarian approach. This view has been set against the three dominant theories which interpret social conduct and orientations in slum areas as being fundamentally irrational.

Some have gone to the slum settlement in search of the excitement of of Greater Buenos Aires', United Nations (1958); Guillermo Briones, 'Movilidad Ocupacional y Mercado de Trabajo en el Peru', America Latina, 6:3 (1963); William Flinn, 'Rural-toUrban Migration: A Colombian Case', Land Tenure Center Research Publication no. 19, University of Wisconsin (1968); Frank Bonilla, 'Rio's Favelas, the Rural Slum within the City', American University Field Staff Reports, $8: 3$ (1961); Elsa Usandizaga and A. Eugene Havens, Tres Barrios de Invasion (Bogota: Tercer Mundo, 1966). In the writer's study of peripheral settlements in Santiago, 45 percent of respondents reported that their present occupations were better than before, while 18 percent judged them to be the same. When asked to compare their occupations with the ones to which they had aspired at the beginning of their adult lives, 44 percent found them to be better than or equal to their initial aspirations.

${ }^{31}$ For a recent analysis of black ghetto demands, see Edgar Litt, Ethnic Politics in America (Glenview, Ill.: Scott, Foresman, and Co., 1970).

32 Mangin, op. cit., p. 85. 
finding people who are somehow out of the ondinary an distinctive:breed of men to be pitied, despised, and feared. Superficial familiarity with slum settlements confirms this impression. The external appearance of these areas is always depressing and certainly different from what is usually considered to be the city proper.

In contrast, the consistent results of empirical research suggest that the problems of peripheral slums and their causation are of an essentially structural nature. These problems have nothing to do with a unique 'way of being' or a deviant culture of irrationality. Ways of acting in the slum are structurally determined to the extent that individuals continuously look for the most efficient way of improving their positions within the limits and the barriers created by the existing social and economic organization. Distortions, contradictions, irrationalities are, to be sure, abundant. But they inhere in the broader collective structure of production and distribution. The grave mistake of theories on the urban slum has been to transform sociological conditions into psychological traits and impute to the victims the distorted characteristics of their victimizers. Practically, the unquestioned assumption of slum irrationality has led to unrelenting proddings toward self-fulfillment of the worst predictions. The necessity for a shift in theoretical orientations stands in direct relation to the urgency of preventing these consequences from continuing in the future. 